\title{
Regional Congress of the Commonwealth Medical Association
}

\author{
AUDREY A. McFARLANE, \\ B.Sc. Physiotherapy (Wits), \\ Dip. in Education, Pretoria, \\ Senior Lecturer Ga-Rankuwa.
}

My decision to attend the Lesotho Medical Congress as a way of spending the long week-end in October turned out to be very gratifying both from the academic as well as the aesthetic points of view. It was a Regional Congress of the Commonwealth Medical Association and the theme was Orthopaedic Rehabilitation. It was held in Maseru the 9th-12th October, 1975, and was attended by doctors from the member Medical Associations of Botswana, Kenya, Malawi, Swaziland, Tanzania, Uganda and Zambia. Also there, were representatives from the invited guest associations, namely the British Orthopaedic Association, the South African Orthopaedic Association and the South African Society of Physiotherapy besides speakers from the United States and Rhodesia.

The congress was held in the Airport Hotel in Maseru and was opened by His Majesty King Constantine Moshoeshoe II, patron of the Lesotho Medical Association. His address ended with a plea that the pressing practical problems be not lost in the clouds of high scientific and academic considerations. Dr. M. A. Siddique, O.B.E., convened the congress and the chief guest speaker was Prof. W. Brodie, Head of the Department of Orthopaedics at the University in Kampala, Uganda. Prof. Brodie read a number of papers well illustrated with slides. $\mathrm{He}$ emphasised the point that sophisticated wheelchairs with pneumatic tyres have no place in rural Black communities. He showed the making of a simple wheelchair from a normal tubular chair with solid-tyre wheels and a back wheel of at least eight inch diameter for rough roads. He also showed the making of simple calipers from steel rods (used to re-inforce concrete) with leather parts made of sheepskin and the shoe replaced by a wooden clog with straps over the foot. The making of these calipers provides employment for the handicapped.

Orthopaedic Surgeons from South Africa who read papers included Mr. J. A. v.d. Merwe, President of the S.A. Orthopaedic Association. Prof. Pompe van Meerdeervoort from the University of O.F.S. and Mr. J. E. Handelsman from The University of the Witwatersrand. The President of the British Medical Association Mr. P. H. Newman also read a paper.

These papers were on Cerebral Palsy, Deformities and Injuries, and to mention just one point that interested me, was the refuting of the fact that the low incidence of Congenital deformity of the hip joint in Blacks is due to a dislocatable hip being cured by "back carrying". Apparently this could only be the explanation if the child were carried in this way from the day of birth but this is not so. The babies are not carried on the back until they are at least three or four weeks old during which time they are swaddled in cloths with their legs adducted. The low incidence must be due to other factors which as yet are not verified.

Four physiotherapists from South Africa read papers. The number that travelled from South Africa to attend being ten members of the South African Society of
Physiotherapy, three with spouses, making a group of thirteen in all. This was re-inforced by three physiotherapists from Lesotho Miss F. Morojele, Miss Mofokeng and Mrs. Bedwani ('an Egyptian). Besides myself from Pretoria, the others from South Africa were $\mathrm{Mrs}^{\wedge}$ Lindsay Woods (and her husband) and Miss Hazel Smitth) from Port Elizabeth, (Dr. and) Mrs. Morar and Miss Rita Meyer from East London, Mr. John Moot from Cape Town who read a paper on Paraplegia; from Durban Mr. Charles Liggins who read a paper on T.B. Meningitis and Mr. Gounden who read a paper on Neonatal Tetanus; and from Bloemfontein Mr. Rogers, and Mrs. Lederle who read a paper on Building a Rehabilita. tion Service with Limited Resources.

Mr. Gounden's paper raised discussion on the low incidence of Neo-natal Tetamus in Lesotho. The paper showed a low incidence in the O.F.S. compared to Natal and Lesotho adjoins the O.F.S. Physiotherapy was much in evidence throughout the congress - the various surgeons mentioning it frequently in their papers, - - and the whole atmosphere was very gratifying for physiotherapists.

The interesting sessions were punctuated by enjoyable social functions and we were feted and entertained throughout the Congress. For our arrival at the airport there was a welcoming committee consisting of the Convenor Dr. Siddique, his secretary Mrs. Vivian, the President of the Lesotho Medical Association Dr. Lebona and his wife Evelyn who took us to a luncheon at the Maseru Club and then on to a conducted tour of the Queen Elizabeth II Hospitall in the afternoon.

The Delegates were entertained by King Moshoeshoe II to a cocktail party at the palace the evening after he/ had opened the Congress. The Minister of Health held a cocktail party at the Maseru Club on the second evening from where delegates divided into smaller groups to be entertained at dinner parties in the private homes of members of the Lesotho Medical Association, and an enormous banquet was held in the Airport Hotel on the following evening. At the closing ceremony all delegates were presented with Lesotho hats and flags and we ended with a wonderful trip to Molimo Nthuse (God Help $\mathrm{Me}$ ) in the Maluti mountains where we lunched on delicious fresh trout from the mountain streams.

The congress felt that the successful coming together of all the land's of Southern Africa should not melt away but produce fruitful results so various practical resolutions were drawn up at the final session. Among other things it was decided to build a "Kraal" in Lesotho where disabled lived for a day or two after completion of hospitalisation to integrate them into their community living before returning to their families. This was as the result of a paper read by an Occupational therapist from Bloemfontein where such a kraal has been built. Also that triple innoculation against Polio must become a fact. One felt that the wish of the King would be fulfilled by the carrying out of the final Resolutions. 


\section{GENERAL}

\section{NATIONAL COMMITTEE OF REPRESENTATIVES}

At the recent National Council Meeting a completely At concept for the Administration of the Society was discussed. The Council agreed that we try out the scheme discuscertain whether it would in fact, function as invisaged.

It was agreed that we appoint a smali National Executive Committee who would meet regularly and be Execunsible for the day-to-day business of the Society. These Meetings would not be attended by representatives the Associations, Groups or Branches unless some of thent business required discussion.

A National Committee of Representatives would also be appointed. This would consist of the members of the National Executive Committee together with a represenrive from all the Branches, Associations, Groups, Chairin of the Sub-Committees, Officers of the Society, such is the Public Relations Officer and representatives of the Society on National Organisations.

This Committee has been formed in an endeavour to make the running of the Society more "national" especially as far as Branch representation is concerned.

It is fully appreciated, however, that at present it will not be possible for Branches to be represented personally at each meeting, as the expenses involved are prohibitive. It is the aim of the Society, however, to make this possible eventually, and both the National Executive Committee and the Branches must work towards this end. Where a Branch is not domiciled in the area of the Headquarters and cannot send a representative to any particular meeting. an alternate residing in the area must be appointed (Johannesburg or Pretoria). If a Branch wishes to discuss a matter urgently and wishes to send a representative from their own Branch the expenses shall only be borne by the Society if authorised previously by the National Executive Committee. (See Amendments to Constitution passed at Council 36 (c)).

The number of meetings that this Committee of Representatives will hold annually will be decided upon by the Committee itself at its first meeting. At the recent National Executive Committee Meeting it was agreed that the first meeting would be convened for Saturday 31st January, 1976. It will be held in Johannesburg, the enue will be notified at a later date.

\section{SPECIAL INTEREST GROUPS}

South African Society of Physiotherapy

Addresses :

Obstetric Association

Secretary: Mrs. B. Kastell,

11 Bath Avenue, Parkwood

Johannesburg 2000.

Telephone: $42-7410$

Manipulative Therapists Group

Secretary: Miss B. Winter,

801 Jan. S. Marais M dical Centre,

Bellville Cape 7530.

Telephone: $97-8644$

\section{EDITOR'S NOTE}

Journals of Member Organisations and W.C.P.T. are received regularly by the S.A.S.P. and these are available ON LOAN to members on application to the Editor, P.O. Box 1151, Johannesburg.

\section{INTERNATIONAL CONGRESS OF PHYSIOTHERAPY}

The Organizing Committee of the XVI INTERNATIONAL CONGRESS OF PHYSIOTHERAPY has been set up in Barcelona. Working sessions will be held in the Hall of Congresses from June 20 to 25 , 1976.

The Congress, sponsored by C.E.T.P., is organized by the Spanish Physiotherapy Association, represented by the Barcelona delegation.

The Science Committee has chosen the following monograph topics:

(a) Physiotherapy treatment in spastic paralysis.

(b) Recovery of the use of the hand.

(c) Functional treatment of spinal pathologies.

A paper on each of these topics will be presented by an outstanding personality in the field.

The Congress will admit communiqués on these topics, as well as free commuriqués, and will dedicate a full day of the Congress to them.

The date for reception of the communique summaries is March 1; instructions and forms may be requested from the Secretariat.

Parallel to the Congress there will be an exhibit of professional technical material which will include important firms from around the world.

In my own name and that of the Organizing Committee, it is my pleasure to cordially invite all our colleagues in this country, whose attendance and scientific collaboration will be a great satisfaction for us.

\section{ALBERTO NUNEZ PEREZ,}

Organizing Committee Chairman.

XVI Congreso International de Fisioterapia

- Secretaria - Apartado 22055 Barcelona (Espana).

\section{A. C. MILLER \& CO. ORTHOPAEDIC MECHANICIANS}

Technicians registered with S.A. Medical and Dental Council specialising in the following: ORTHOPAEDIC APPLIANCES, SURGICAL CORSETS, CERVICAL COLLARS, CHILDREN'S SHOES AND BOOTS, ARTIFICIAL LIMBS, LATEST IN PLASTIC MODIFICATION. HIRING AND SELLING OF HOSPITAL EQUIPMENT AND SICK ROOM REQUISITES, e.g. WHEEL CHAIRS, COMMODES, HOSPITAL BEDS, WALKING AIDS, TRACTION APPARATUS, etc.
Telephone 23-2496
P.O. Box 3412 275 Bree Street

\section{Johannesburg}

